\title{
Ex situ Conservation of Three Endemic and/or Endangered Dianthus Species
}

\author{
Victoria CRISTEA ${ }^{1}$, Liliana JARDA ${ }^{1}$, Irina HOLOBIUC ${ }^{2}$ \\ 1 "Babeş-Bolyai” University, "Alexandru Borza” Botanical Garden, 42 Republicii str, 400015, Cluj-Napoca, Romania; victoria.cristea@ubbcluj.ro \\ ${ }^{2}$ Institute of Biology-Romanian Academy, 296 Splaiul Independenței, 060031, Bucureşti, Romania
}

\begin{abstract}
Within the current context of declining biodiversity, the botanical gardens play an essential role in its conservation. Dianthus callizonus, D. glacialis ssp. gelidus and D. spiculifolius are the species that we seek to preserve in "Alexandru Borza" Botanical Garden of Cluj-Napoca (Romania). Several replicates were collected for each taxon from different populations in order to avoid the genetic uniformity. The material collected from the natural sites, was planted on a rockery, specially designed for this collection in the Botanical Garden. At the time of planting, each individual was sampled for setting up an in vitro collection and further biochemical and molecular analyses. In case of ex situ outdoor conservation of the three Dianthus species, $80.6 \%$ of the individuals collected in the field survived during the first year but the percentage decreased drastically after four years. In the case of in situ collected individuals, as well as in the case of in vitro individuals, D. spiculifolius had the best ability to acclimatize in the Botanical Garden, and D. callizonus presented the lowest number of surviving individuals. The ex vitro acclimatization of the plantlets had $80 \%$ efficiency at $10^{\circ} \mathrm{C}$, using three different substrates: soil and pearl stone mix $1 / 1$, soil and sand mix $1 / 1$ and pearl stone. All the three species are preserved in vitro, whereas the plantlets are acclimatized outdoors. Ex situ conservation of these species will have a positive impact on the biodiversity conservation.
\end{abstract}

Keywords: Dianthus callizonus, Dianthus glacialis ssp. gelidus, Dianthus spiculifolius, from vitro plantlets acclimatization, Natura 2000 sites

\section{Introduction}

In recent years, global biodiversity declined drastically, according to the 2006 IUCN Red List: out of the 40,177 species assessed, 16,119 are now listed as threatened with extinction (IUCN, 2006). In addition, the IUCN listed 8,321 plant species (out of the 11,824 evaluated) as threatened in 2004 (Baillie et al., 2004). An efficient approach for plant conservation is achieved by combining in situ and ex situ conservation methods with the main goal of maintaining an optimum/high genetic diversity for the chosen species. For in situ conservation a large network has been established in Europe (i.e., NATURA 2000), comprising over 26,000 protected areas covering all the Member States (around $850,000 \mathrm{~km}^{2}$, representing more than $20 \%$ of total EU territory) (EAP, 2011).

Ex situ conservation consists of a complex of various complementary proceedings, carried out in a different ecological environment than the characteristic one for the target species (Cristea and Denaeyer, 2004). These authors include thematic collections (working collections, active or basic collections), gene banks or in situ conservatories, in their envisioned conservation system. The botanical gardens represent traditional centers for the ex situ conservation of plant material as living collections. They successfully contribute to ex situ conservation of a high number of endemic and/or endangered plant species using combined methods: classical outdoor or greenhouses cultivation, seeds banks and in vitro collections. A survey indicated that out of 119 European botanical gardens in 29 European countries, 105 are cultivating 308 of the 573 threatened plant species listed by the Bern Convention. The survey identified 25 botanical gardens in 14 countries undertaking 51 conservation projects focused on 27 Bern listed species (Maunder et al., 2001). Besides the studies of flora and phytosociology (Puşcas et al., 2012), there is permanent concern for the enrichment of endemic and/or threatened outdoor plant collections (Hentea et al., 2004; Şuteu et al., 2004), in "Alexandru Borza" Botanical Garden of Cluj-Napoca (Romania).

The aim of this study is the creation of an outdoor $e x$ situ conservation for 3 alpine or subalpine Dianthus species, endemic to the South-Eastern Carpathians (Coldea et al., 2009; Hurdu et al., 2012): D. callizonus Schott \& Kotschy, D. glacialis Haenke ssp. gelidus (Schott, Nyman \& Kotschy) Tutin and D. spiculifolius Schur. We've embarked on this project knowing that the Romanian botanical gardens only have a few endemic and/or threatened Dianthus species. Some studies using in vitro culture for these species have been done already in the lab (ButiucKeul et al., 2001; Cristea et al., 2002; 2006; Holobiuc and Blîndu, 2006; Zăpârțan, 2001), but the plant material came mostly from various collections, rather than their natural sites. Still, the ex situ outdoor conservation aspects for many species with sozological importance have not been tackled yet. Also, systematic studies regarding ex 
74

vitro acclimatization of sozologically important species of Romania are lacking. Due to an accelerated degradation of natural habitats, including the subalpine and alpine ones, the existence of these collections will have a significant impact for future repopulations.

\section{Material and methods}

\section{The studied species}

D. callizonus is one the most emblematic Carpathian species, being strictly localized in the Piatra Craiului Mountains (Ciocârlan, 2000; Prodan, 1953). Old botanical literature reported the species also from Bucegi Mountains (Haret, 1938; Negrean, 1979; Negrean and Oltean, 1989; Simonkai, 1886), but the occurrence in that massif was not confirmed by subsequent explorations (Dihoru and Negrean, 2009). D. callizonus grows on alpine and subalpine calciphilous grasslands (Ciocârlan, 2000; Mihăilescu, 2003). This is a perennial species, with a 10$20 \mathrm{~cm}$ single-flowered (seldom 2-5) unbranched stem. The basal leaves are shorter than those on the stem and often form rosettes. The lanceolate leaves are much wider at the base. The flowers, which are very beautiful, have a carmine colour, the lamina of the petals being spotted in its upper part (Prodan, 1953). The National Red Lists (Sârbu, 2003) and Dihoru and Negrean (2009) indicated the species as being vulnerable or with lower risk. Seven individuals were sampled from a single population in Piatra Craiului Mountains (Fig. 1):

- Population 1 - Piatra Craiului Mountains (Piatra Craiului Mică), NATURA 2000 Site ROSCI0194, alt. $1626 \mathrm{~m}$ a.s.1. ( $45^{\circ} 28^{\prime} 21^{\prime \prime} \mathrm{N}, 25^{\circ} 11^{\prime} 30^{\prime \prime} \mathrm{E}$ ).

D. glacialis ssp. gelidus is endemic to the Eastern and Southern Carpathians (Romania), with a sporadic distribution in the alpine belt of these mountains. The largest and most abundant populations are in the Bucegi, Făgăraş and Rodna Mountains (Romania) (Mihai Puşcaş, personal communication). It grows mainly in alpine primary herbaceous communities developed on bedrocks rich in carbonate rocks. This perennial, caespitose species has short stems (less then $10 \mathrm{~cm}$ ) with solitary pedicellate flowers. The leaves are wider towards the tip. The petal's lamina is dark-rosy (Ciocârlan, 2000; Prodan, 1953). D. glacialis ssp. gelidus is mentioned in the Romanian Red Lists as vulnerable (Sârbu, 2003). The taxon was sampled from 3 different populations ( 5 individuals per sample) (Fig. 1):

- Population 1 - collected from Bucegi Mountains (Omu Peak), NATURA 2000 Site ROSCI0013, alt. 2400 m a.s.l. (45'22'51" N, 25'30'40” E);

- Population 2 - collected from Făgăraş Mountains (Bâlea Lake), NATURA 2000 Site ROSCI0122, alt. 2160 m a.s.l. (45०31'40” N, 24\%44'26" E);

- Population 3 - collected from Bucegi Mountains (Obârşia), NATURA 2000 Site ROSCI0013, alt. 2417 m a.s.l. (45'22'50” N, 25'30'39” E).
D. spiculifolius has a broader distribution area in South-Eastern Carpathians, present in Romania (Apuseni Mountains, Southern and Eastern Carpathians), as well as in the Ukrainian Carpathians (Ciocârlan, 2000; Prodan, 1953 Tutin, 1964). It grows mainly on calcareous rocky outcrops and cliffs especially in the mountain to subalpine belt (Coldea, 1991). This perennial, caespitose species, is shorter then $20 \mathrm{~cm}$, having numerous stems, each bearing 2-5 pairs of leaves and 1 (2) white or pink flowers. (Ciocârlan, 2000; Prodan, 1953). This species is mentioned in the Romanian Red List as vulnerable (Sârbu, 2003). D. spiculifolius was sampled from 2 different populations (4-5 individuals from each) (Fig. 1):

- Population 1 - collected from Hăşmaş Mountains (Bicaz Gorges), NATURA 2000 Site ROSCI0027, alt. 1668 m a.s.l. (4644’27”N, 25\%47'58” E);

- Population 2 - collected from Apuseni Natural Park, Vlădeasa Massif (Pietrele Albe), NATURA 2000 Site ROSCI0002, alt. $1050 \mathrm{~m}$ a.s.l. (N 463' 45” N, 22\%48'38”E).

\section{Ex situ outdoor acclimatization of wild plant species}

We set up a new rockery in the "Alexandru Borza" Botanical Garden from Cluj-Napoca (Romania), for the ex situ collection. The soil in the pockets was rich in limestone rock crumbs since the 3 species are calciphilous. At the same time, we used the original soil ball from the sampling spot, for planting. Individuals of the same population were planted in the same pocket, with space between them. Three-five individuals were planted in a pocket, according to its size. Initially the planted individuals have been shaded with a special net for a faster acclimation. During the four wintering periods, the rockery didn't have any special protection, considering that the species are alpine or subalpine. The planted material was monitored for four years $(2008$ - 2012) recording the number of generated shoots each year and the number of flowering stems/ each individual. The seed were collected and kept at $4^{\circ} \mathrm{C}$.

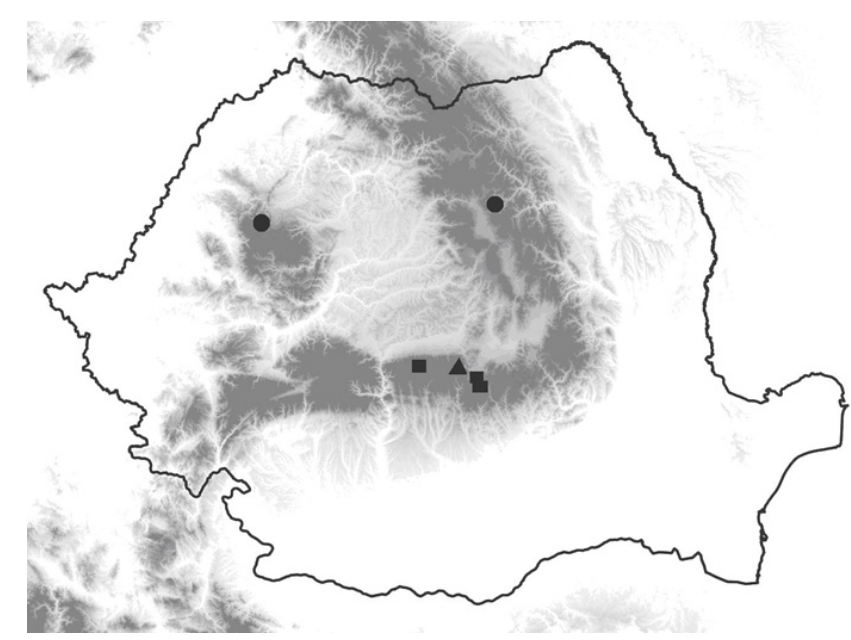

Fig. 1. Location of the studied populations of D. callizonus $(\boldsymbol{\Delta})$, D. glacialis ssp. gelidus ( $)$ and D. spiculifolius (•) in Romania 


\section{Ex situ outdoor acclimatization of plantlets}

Leaf fragments from each wild individual were sampled and stored for in vitro culture, further biochemical and molecular analyses. Three experimental variants were used for the acclimatization of plantlets generated in vitro: soil and pearl stone mix $1 / 1$, soil and sand mix $1 / 1$ and pearl stone. The plantlets were kept at $25^{\circ} \mathrm{C}$ and $10^{\circ} \mathrm{C}$, in parallel, for the first 4 weeks. The atmospheric humidity was high, close to $80 \%$, in the first 10 days and gradually decreased. The culture substrates were watered daily with MS solution of macro and microelements $1 / 4$ diluted (Murashige-Skoog, 1962). The plantlets generated in vitro were acclimatised and planted outdoor, on a secondary rockery, different from the one used for plants brought from nature.

\section{Statistical analysis}

Using statistical analysis tools we compared the intraand interpopulational variability of the plants collected in the wild and adapted to the conditions in the Botanical Garden. The individuals of each population and the populations of each species were compared. GraphPad Prism, version 5.00 for Windows, was used. One-Way ANOVA test (for testing 3 or more columns) or the t tests (for testing 2 columns), with a $95 \%$ confidence intervals was used. When ANOVA test showed significant differences, Tukey's post test was used in order to determine the significance of the differences between the average values at $p<0.05$.

\section{Results and discussion}

Ex situ outdoor acclimatization of wild plant species

The first collected individuals of the namely $D$. callizonus, D. glacialis ssp. gelidus and D. spiculifolius, planted in June - August 2008, generated new shoots over the summer. Many plants, brought with buds or flowers from their

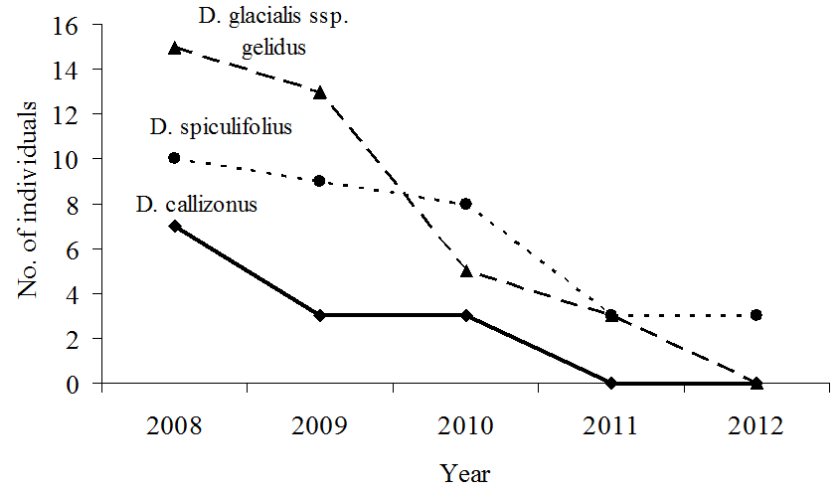

Fig. 2. D. callizonus, D. glacialis ssp. gelidus and D. spiculifolius 4 years evolution in the "Alexandru Borza" Botanical Garden of Cluj-Napoca (Romania). Anova test results: there are no significant differences between the different populations of the same species

natural sites, produced flowers and fertile seeds. During the observations, after one year $80.6 \%$ of the individuals were viable (Fig. 2, 3a, 4a and 5a).

As shown in Fig. 2, the studied species had a different evolution during the four years of monitoring. The best results were those of D. spiculifolius, which in the third year presented approximately the same number of shoots as in the first year and a greater number of flowering stems (Tab. 1 and 2). However, only three of the ten planted individuals were acclimatized in the case of this species. D. glacialis ssp. gelidus lived only for three years under the conditions of the Botanical Garden, and even though in the first and second year they bloomed, no flowering stems formed in the third year (Tab. 2).D. callizonus suffered the most as a result of transplantation in the Botanical Garden conditions, living and blooming only for one year (Tab. 1 and 2).

About two dozen individuals of all studied species (five individuals of $D$. callizonus, 12 individuals of $D$. glacialis ssp. gelidus, and 5 individuals of D. spiculifolius), bloomed Tab. 1. Multiplication of D. callizonus, D. glacialis ssp. gelidus and D. spiculifolius, during four years, in the "Alexandru Borza" Botanical Garden of Cluj-Napoca (Romania)

\begin{tabular}{ccccccccc}
\hline \multirow{2}{*}{ Species } & \multicolumn{2}{c}{2009} & \multicolumn{2}{c}{2010} & \multicolumn{2}{c}{2011} & \multicolumn{2}{c}{2012} \\
\cline { 2 - 8 } & NoS/Sp & ANoS/I & NoS/Sp & ANoS/I & NoS/Sp & ANoS/I & NoS/Sp & ANoS/I \\
\hline D. callizonus & $27^{*}$ & $9.00 \pm 3.46^{*}$ & 0 & 0 & 0 & 0 & 0 & 0 \\
D. glacialisssp. gelidus & $113^{\mathrm{ns}}$ & $8.69 \pm 4.11^{\mathrm{ns}}$ & $69^{\mathrm{ns}}$ & $16.50 \pm 1.73^{\mathrm{ns}}$ & $45^{\mathrm{ns}}$ & $15 \pm 7.00^{\mathrm{ns}}$ & 0 & 0 \\
D. spiculifolius & $100^{\mathrm{ns}}$ & $12.25 \pm 8.01^{\mathrm{ns}}$ & $250^{\mathrm{ns}}$ & $29.83 \pm 9.47^{\mathrm{ns}}$ & $135^{\mathrm{ns}}$ & $45 \pm 7.00^{\mathrm{ns}}$ & $53^{\mathrm{ns}}$ & $24.33 \pm 8.50^{\mathrm{ns}}$ \\
\hline
\end{tabular}

$\mathrm{NoS} / \mathrm{Sp}=$ Total number of shoots/species. ANoS/I = average number of shoots/individuals; the data in the $2^{\text {nd }}$ column of each year are presented as mean \pm SD. ${ }^{*} \mathrm{p} 0.01$ to $0.05 ;$ is $p>0.05$ no statistical significance

Tab. 2. Number of flowering stem of $D$. callizonus, D. glacialis ssp. gelidus and D. spiculifolius, during four years, in the "Alexandru Borza” Botanical Garden of Cluj-Napoca (Romania)

\begin{tabular}{ccccccccc}
\hline \multirow{2}{*}{ Species } & \multicolumn{2}{c}{2009} & \multicolumn{2}{c}{2010} & \multicolumn{2}{c}{2011} & \multicolumn{2}{c}{2012} \\
\cline { 2 - 8 } & NoS/Sp & ANoS/I & NoS/Sp & ANoS/I & NoS/Sp & ANoS/I & NoS/Sp & ANoS/I \\
\hline D. callizonus & $13^{*}$ & $4.33 \pm 1.52^{*}$ & 0 & 0 & 0 & 0 & 0 & 0 \\
D. glacialis ssp.gelidus & $66^{\mathrm{ns}}$ & $5.33 \pm 3.52^{\mathrm{ns}}$ & $80^{\mathrm{ns}}$ & $19.25 \pm 6.65^{\mathrm{ns}}$ & 0 & 0 & 0 & 0 \\
D. spiculifolius & $29^{\mathrm{ns}}$ & $2.50 \pm 1.22^{\mathrm{ns}}$ & $164^{\mathrm{ns}}$ & $19.00 \pm 12.01^{\mathrm{ns}}$ & $21^{\mathrm{ns}}$ & $32.66 \pm 7.50^{\mathrm{ns}}$ & $26^{\mathrm{ns}}$ & $12.00 \pm 4.69^{\mathrm{ns}}$ \\
\hline
\end{tabular}

$\mathrm{NoS} / \mathrm{Sp}=$ Total number of shoots/species. ANoS/I = average number of shoots/individuals; the data in the $2^{\text {nd }}$ column of each year are presented as mean \pm SD. ${ }^{*} \mathrm{p} 0.01$ to $0.05 ;{ }^{\text {ns }} p>0.05$ no statistical significance 
76

and set seed, after the first year of culture in the Botanical Garden. However, after four years of observation only $D$. spiculifolius did so, whereas the other 2 species didn't survive in the Botanical Garden.

The statistical analyzes reveal a reduced variability among the different individuals or populations regarding their acclimatization ability. D. callizonus had only one individual whose response was different from the rest. For $D$. glacialis ssp gelidus, the intrapopulational variability was low and there was no interpopulational variability. In case of $D$. spiculifolius there is no intra or interpopulation variability.

The results above illustrate an evolution below expectations for the evolution of plant material collected in the wild and transplanted in the "Alexandru Borza" Botanical Garden of Cluj-Napoca (Romania). Two of the species D. callizonus and D. glacialis ssp. gelidus - did not succeed in getting acclimatized. That could be due to the fact that the first species is a subalpine one, whereas the latter is alpine, being hekistotherm (adapted to lower temperatures) by nature (Ciocârlan, 2000). The rokery where they were planted in the Botanical garden is at $402 \mathrm{~m}$ a.s.l. (which corresponds to the zone of oak forests, possibly beech). These climatic conditions are too divergent from those found in situ and could explain the constant decline of the individuals from the two species. The third species, which managed to get acclimatized, D. spiculifolius, is mainly found at altitudes corresponding to beech forests, all the way to the subalpine level (Ciocârlan, 2000). Therefore it grows in conditions that are more or less similar to those of the Botanical Garden. Another problem could be that the individuals brought to the Botanical Garden lack the phytosociological conditions from the wild. Hence the need for collecting surrounding species in the future, in a wider soil block, if conservation of endemic or endangered species is sought under these conditions. An alternative would be to collect seeds from in situ locations and later grow them ex situ, as recommended by other authors (Mikatadze-Pantsulaia et al., 2012). Similar to our study, these authors studied more endemic and protected species in Georgia first by in situ observation and then conserving them by seed bank and seedling production for the purpose of in situ restoration. More or less similar studies on ex situ conservation were carried out for other endemic or endangered Dianthus species. D. diutinus Kit. individuals (endemic for Hungary and for the $\mathrm{E}$ of former Yugoslavia) were grown from seeds for the repopulation of their natural sites at the University of Szeged. The generative state of the individuals could be reached within one year. Plants grown in pots by ex situ propagation were out-planted in their natural site where the number of the individuals was critically low (Németh et. al., 2011). The ecology and population dynamics of Dianthus armeria L., spread in Western, Central and Southern Europe but included in English Nature's Species Recovery Programme was investigated at the University of Sussex, and research into the seed biology and germination ecology were carried out (Garnnet, 2004).

\section{Ex situ outdoor acclimatization of plantlets}

At present, in vitro collections for the studied species are available. The ex vitro acclimatization experiments of the in vitro generated plantlets had a good efficiency $(80 \%)$, especially at $10^{\circ} \mathrm{C}$, in all of the experimental variants and with all the species. The plantlets were cultivated on another rockery to differentiate between the 2 types of individuals (wild vs. in vitro culture) (Fig. 3b, $4 \mathrm{~b}$ and $5 \mathrm{~b}$ ).

In the case of outdoor acclimatization of plantlets, $D$. spiculifolius also had the best multiplication rate, $136.4 \%$ after 2 years from planting while $D$. callizonus reached $125 \%$ (Tab. 3). The number of D. glacialis ssp. gelidus plants decreased by $33.3 \%$ after 2 years of outdoor culture.

The already published studies regarding the in vitro multiplication of the analyzed species (Butiuc-Keul et al., 2001; Cristea et al., 2002, 2006; Holobiuc and Blîndu, 2006) do not contain details on the ex situ acclimatization. The results presented here on the ex situ acclimatization of in vitro generated plantlets meet the expectations, having a superior efficiency. We have to stress out that the evolution had by the in vitro generated plantlets outdoor is supperior to that of plants collected in situ and transplanted in the Botanical Garden. Because of that we consider in vitro multiplication as being the best suited technique for endemic and/or threatened species in botanical gardens. Plus, this has the advantage of avoiding the negative impact of collecting species from their natural habitat. In order to avoid possible genetic changes induced by the in vitro culture, these plants must be genetically certified. Therefore we already performed SSR molecular studies on D. spiculifolius in order to monitor the somaclonal variability (submitted data), and we are currently working on the other two species (D. callizonus and D. glacialis ssp. gelidus).

Our present results on ex vitro acclimatization are in accord to those reported by other authors (Gorgorov et al., 2011) who micropropagated three endemic and rare Alchemilla species, adapted them ex vitro and then transferred the surviving plants to a mountaneous environment. This study also reports that only two of the three species could be acclimatized, with a reduced rate due to low humidity stress. However, the adaptation efficiency in natural habitat conditions afterwards, was high.

Tab. 3. Outdoor aclimatization of plantlets, in "Alexandru Borza” Botanical Garden of Cluj-Napoca (Romania)

\begin{tabular}{cccccccc}
\hline \multirow{2}{*}{ Species } & \multicolumn{3}{c}{ No. of shoots } & \multicolumn{3}{c}{ No. of flowering stems } \\
\cline { 2 - 7 } & 2010 & 2011 & 2012 & 2010 & 2011 & 2012 \\
\hline D. callizonus & 4 & 18 & 5 & 0 & 2 & 0 \\
D. glacialis ssp. gelidus & 6 & 4 & 4 & 0 & 2 & 2 \\
D. spiculifolius & 44 & 48 & 60 & 0 & 12 & 26
\end{tabular}




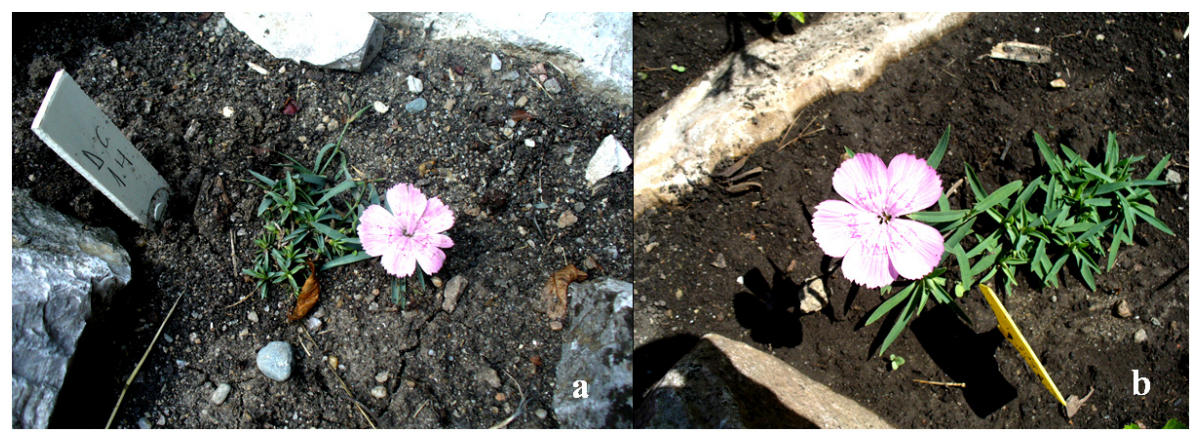

Fig. 3. Outdoor ex situ collection of D. callizonus on the rocky area in „Alexandru Borza” Botanical Garden (Romania); a. plants collected from situ in 2008, after 11 months; b. outdoor cultivated plantlets

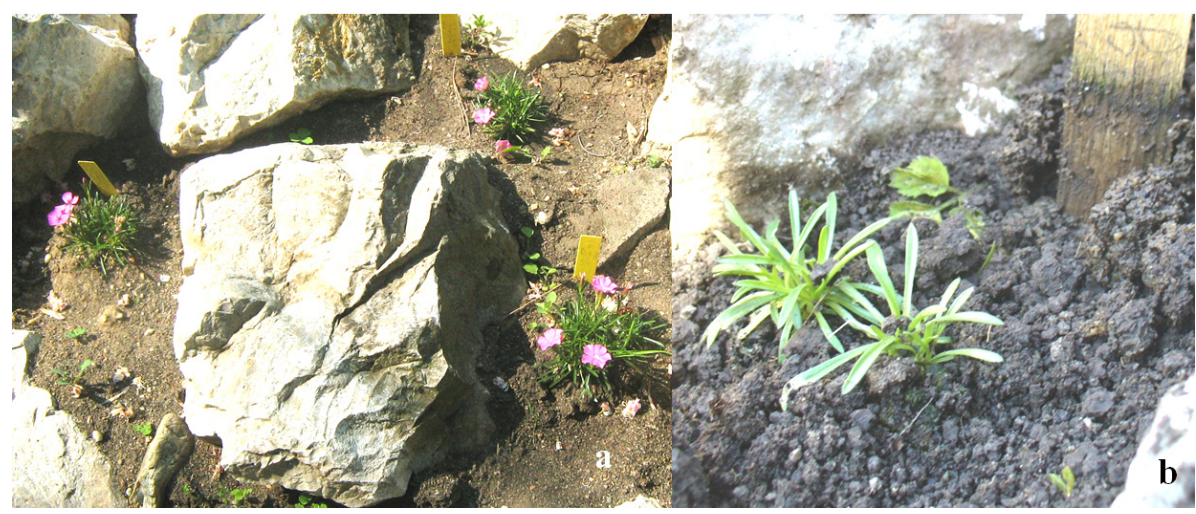

Fig. 4. Outdoor ex situ collection of $D$. glacialis ssp. gelidus, on the rocky area in „Alexandru Borza" Botanical Garden (Romania); a. plants collected from situ in 2008, after 10 months; b. outdoor cultivated plantlets

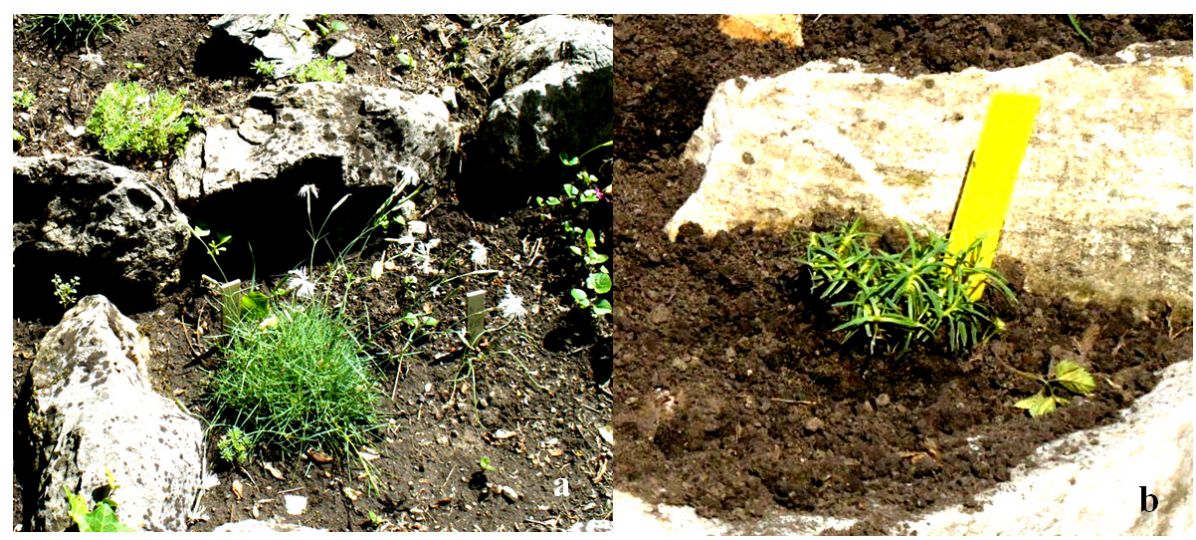

Fig. 5. Outdoor ex situ collection of D. spiculifolius, on the rocky area in "Alexandru Borza” Botanical Garden (Romania); a. plants collected from situ in 2008, after 1 year; b. outdoor cultivated plantlets

\section{Conclusions}

In the course of four years of observations on cultivated endemic and endangered species of $D$. callizonus, D. glacialis ssp. gelidus and D. spiculifolius in "Alexandru Borza" Botanical Garden of Cluj-Napoca (Romania) that have been collected in situ and replanted, only the last one managed to survive acclimatization/adaptation. However, in the case of plantlets generated by in vitro culture they adapt and survive much better to outdoor conditions.

\section{Acknowledgement}

This study has been supported by the 31-008/2007 grant from the Romanian Ministry of Education and Research on the framework of "Parteneriate PN II" Programme (CNMP).

\section{References}

Baillie JEM, Hilton-Taylor C, Stuart SN (2004). 2004 IUCN Red List of Threatened Species ${ }^{\mathrm{TM}}$ : A Global Species Assess- 
78 ment. IUCN Publications Services Unit, 193 p.

Butiuc-Keul A, Şuteu A, Munteanu-Deliu C, Deliu C (2001). Study on the in vitro preservation of Dianthus spiculifolius Schur. Contrib Bot 36:137-143.

Ciocârlan V (2000). Illustrated Flora of Romania, Pteridophyta et Spermatophyta, Ed. Ceres, Bucureşti, 1141 p (in Romanian).

Coldea G (1991). Prodrome des associations vegetales des Carpates du Sud-est (Carpates roumaine). Doc phytosociologiques 13:317-539.

Coldea G, Stoica IA, Puşcaş M, Ursu T, Oprea A, Intrabiodiv Consortium (2009). Alpine-subalpine species richness of the Romanian Carpathians and the current conservation status of rare species. Biodiv Conserv 18:1441-1458.

Cristea V, Denaeyer S (2004). From biodiversity to GMO?. Ed. Eikon, Cluj-Napoca (in Romanian).

Cristea V, Miclăuş M, Puşcaş M (2002). Influence of hormone balance and in vitro photoautotrophy on Dianthus spiculifolius Schur micropropagation. Contrib Bot 37:145-153.

Cristea V, Puşcaş M, Miclăuş M, Deliu C (2006). Conservative micropropagation of some endemic or rare species from the Dianthus genus. Acta Hort 725:357-364.

Dihoru G, Negrean G (2009). Red Book of Vascular Plants of Romania. Ed. Academiei Române, București (in Romanian).

EAP (2011). Introduction to the $6^{\text {th }}$ Environment Action Programme (6th EAP). Available online at: http://nuke.youngparliament.eu/Portals/0/pdf/EU Priorities Environment. pdf.

Garnett S (2004). Dianthus armeria L. Deptford Pink, Fflwyblod y Deptfordd. Available online at: http://adlib.everysite.co.uk/resources/000/091/223/DP_summary.pdf.

Gorgorov R, Stanilova M, Vitkova A (2011). In vitro cultivation of some endemic and rare Alchemilla species in Bulgaria. Rom Biotechnol Lett 16:65-70.

Haret M (1938). National Park in Upper Bucegi Mountains. Rev. Ştiințifică „V. Adamachi” 24(2-3):95-105 (in Romanian).

Hentea S, Şuteu A, Csergö A-M, Puşcaş M, Cristea V, Mocan C, Constantinescu M, Micle F (2004). Threatened plant collections in "Alexandru Borza" Botanical Garden (Romania) for research and conservation purposes. Scripta Bot Belg 29:121-129.

Holobiuc I, Blîndu R (2006). Improvement of the micropropagation and in vitro medium-term preservation of some rare Dianthus species. Contrib Bot 41:143-151.

Hurdu B, Puşcaş M, Turtureanu PD, Niketic M, Vonica G, Coldea G (2012). A critical evaluation of the Carpathian endemic plant species list from the Romanian Carpathians. Contrib Bot 47:39-47.

IUCN (2006). Release of the 2006 IUCN Red List of Threatened Species reveals ongoing decline of the status of plants and animals. Available online at: http://www.natureserve.
org/aboutUs/PressReleases/IUCN_Red_List_release.pdf.

Maunder M, Higgens S, Culham A (2001). The effectiveness of botanic garden collections in supporting plant conservation: a European case study. J Royal Hort Soc 10:383-401.

Mihăilescu S (2003). Protected plant species and fragile habitats of Piatra Craiului Massif, 119-129 p. In: Flora, Research in Piatra Craiului National Park. Ed. Phoenix, Braşov.

Mikatadze-Pantsulaia T, Barblishvili T, Trivedi C, Kikodze D, Khutsishvili M (2012). Ex situ conservation of some endemic and protected plant species in Georgia. Kew Bull 65:643-648.

Murashige T, Skoog F (1962). A revised medium for rapid growth and bioassay with tobacco tissue culture. Physiol Plant 15:473-497.

Negrean G (1979). Rewiev: Al. Beldie, Flora of Romania- illustrated identification guide of vascular plants. Studii Cercetări Biol Ser Biol Veg 31(1):79-81 (in Romanian).

Negrean G, Oltean M (1989). Endemisms and endemic conservative areas from South-Eastern Carpathians. Ocrotirea Naturii Mediului Înconjurător 33(1):15-25 (in Romanian).

Németh A, Mihalik E, Makra O, Balogh L, Szatmári M (2011). Conservation of the Pannon endemic Dianthus diutinus Kit. with ex situ and in situ methods. Proc Ex situ propagation and reestablishment of the Pannonian endemic Dianthus diutinus. Contribution of the Botanic Garden of the University of Szeged to the implementation of the LIFE06 NAT/H/000104 project. Steppe Oak Woods and Pannonic Sand Steppes. Available online at: http://wwf.hu/media/ file/1318412920_Conference_abstract_book.pdf.

Prodan I (1953). The genus 100. Dianthus L., 217-290 p. In: Săvulescu T (Ed.). Flora of Popular Republic of Romania. Ed. Acad. R.P.R., Bucureşti (in Romanian).

Puşcaş M (2012). Distribution and Phytocoenotic Context of Kobresia simpliciuscula (Wahlenb.) Mack. in South-Eastern Carpathians. Not Bot Horti Agrobo 40:29-34.

Sârbu A (coord.) (2003). Guideline for the identification of important protection and conservation plant areas from Romania Ed. Alo!, Bucureşti (in Romanian).

Simonkai L (1886). Enumeratio florae Transsilvanicae vasculosae critica. Budapesta.

Şuteu A, Hentea S, Puşcaş M, Mocan C, Constantinescu M, Micle F (2004). Seed collection of Botanical Garden from Cluj-Napoca - practical modality from "ex situ" conservation. Proc Intern Symp Conceptions and Methods of Nature Conservation in Europe, 52-53 p.

Tutin TG (1964). Dianthus L., 182-204 p. In: Tutin TG, Heywood VH, Burges NA, Valentine DH, Walters SM, Webb DA (Eds.). Flora Europaea I, Cambridge University Press, Cambridge.

Zăpârțan M (2001). Conservation of wild flora by in vitro multiplication. Ed. Alc Media Group, Cluj-Napoca, 152 p. (in Romanian). 